\title{
The Teachers' Competence in the Implementation of Physical Education Learning Program in Elementary Schools of Sawang South Aceh
}

\author{
Dadi Dartija \\ STKIP Bina Bangsa Getsempena Banda Aceh \\ Banda Aceh, Indonesia \\ dadi_mpo@yahoo.com
}

\author{
Sugiharto Sugiharto, Tandiyo Rahayu, Sulaiman \\ Sulaiman \\ University of Negeri Semarang \\ Semarang, Indonesia
}

\begin{abstract}
Teachers are not only required to have knowledge and mastery of teaching materials, but also have the ability to perform administrative tasks related to learning activities. This study aimed to analyze the teachers' competence in the implementation of learning Physical Education in Elementary Schools at Sawang, South Aceh. This research used qualitative approach. The data source of the research was Physical Education teachers at 13 elementary schools in Sawang. The data collection techniques used were observation techniques, interviews, and study of documents. The results show that the competence of teachers in the implementation of learning Physical Education at 13 elementary Schools in Sawang, had not shown optimally. In the implementation of the learning program in the field, all teachers did not perform the learning through the Preliminary stages of activity, core activities, and end activities maximally. The implementation of Physical Education learning program in Sawang Elementary Schools had not run optimally. It was seen that the teachers did not master the material, the use of time allocation which was not efficient, and did not use learning methods that can improve the creativity of students. The findings of the research results become a reference for teachers related to the learning process that has been implemented and stakeholders in order to facilitate teachers through training activities in order to improve and develop teachers' competence.
\end{abstract}

Keywords-learning program; pedagogic competency; physical education

\section{INTRODUCTION}

Education has a pedagogical goal, therefore education is incomplete without physical education, exercise and health, since movement as a physical activity is the basis for human to know the world and they naturally develop by the times [1]. Good physical education, student-centered learning and emphasis on appropriate learning on learning outcomes can also encourage students to become active [2].

Physical education is taught in schools as a subject that combines students learning and physical coaching [3]. According to Francois and Roy, physical activity gives a positive effect in the concentration of learning so as to improve students academic achievement [4]. Lu and Lisio say that physical education is literally a variety of physical activities planned to have individuals who are able to maintain an active and healthy life [5]. Growing a healthy life at an early age provides healthy life practices for students who can later be refined until they grow up [6].

The observation results from January to February 2016 in PJOK learning activities at 15 elementary schools in South Aceh, there were several problems including: 12 teachers did not prepare lesson plans and they delivered learning materials not referring to syllabus and curriculum; all teachers do not use time allocation effectively and efficiently and do not conduct an authentic assessment.

The observations above are in line with a study by Salmawati, et al., showed that many teachers who have not been able to develop syllabus and lesson plan, they have not been able to create LKS (students' work sheet) and their own teaching materials, and the assessment is given only on cognitive aspects only [7].

Teachers as a source of information in the learning process must have a great responsibility in the effort to streamline physical learning, increasing the professionalism of PJOK teachers is merely a non-negotiable demand in facing very competitive challenges [8]. Facing various challenges in the globalization era, it should be the presence and competence of teachers can be considered as good as possible. Teachers are not only required to have knowledge and mastery of teaching materials, but also have the ability to perform administrative tasks related to the professional learning activities.

Teacher competence is a concept used to know in detail about attitudes, knowledge, and skills that must be possessed by teachers [9]. A person is deemed competent in a particular field if the person possesses a skill or workmanship in accordance with the demands of the work field concerned and he has authority in social service in society [10].

The problems obtained in the field as described above become an illustration of the condition of learning PJOK so it is necessary to conduct research that aims to analyze the competence of teachers in the implementation of learning Physical Education, Sports and Health (PJOK) in Elementary Schools in South Aceh. The benefits of this research is expected for teachers to develop and improve the competence 
associated with the implementation of learning PJOK so it can be done optimally.

\section{METHOD}

This research uses qualitative approach with case study type. The source of research data is PJOK teachers in 13 schools using total sampling technique. Data collection using observation instruments, interviews and documentation. The process of collecting data is done by observation stages in the learning activities, conducting interviews on informants related to planning, implementation and evaluation of learning PJOK and document study of learning device completeness.

The data analysis in this research uses Miles and Huberman model that involves data reduction, display data, and conclusion drawing / verification [11]. Steps done in the stages of data analysis, namely the first stage of data reduction that has been collected through observation, interview and documentation and editing or checking the correctness of data and delete the wrong or unnecessary data; The second stage of presenting the data with the description can be graphical or chart; The third stage of data verification or drawing conclusions about the pedagogic competence of PJOK teachers in elementary schools in South Aceh. After the conclusion is complete, it can be used as a recommendation for teachers, principals and supervisors as well as stakeholders to become a reference to make changes and increase the competence of PJOK teachers.

\section{RESULTS AND DISCUSSION}

Based on the observation result, teacher competence in learning activity of PJOK teachers in elementary schools in South Aceh can be described through learning step which include: Preliminary activity, core activity and final activity. The Preliminary activity consists of stretching and warming as well as apperception.

TABLE I. TEACHER ACTIVITY DATA ON PRELIMINARY LEARNING ACTIVITIES

\begin{tabular}{|l|l|c|c|}
\hline \multirow{2}{*}{ No } & \multirow{2}{*}{ Preliminary activity } & \multicolumn{2}{|c|}{$\begin{array}{c}\text { Frequency } \\
(\%)\end{array}$} \\
\cline { 3 - 4 } & & Yes & No \\
\hline 1 & Doing Stretching and Warming & $2(15,4 \%)$ & $11(84,6 \%)$ \\
\hline 2 & Doing Apperception & $2(15,4 \%)$ & $11(84,6 \%)$ \\
\hline
\end{tabular}

Preliminary activities are an important step in the process of physical education as it relates to the activities of learners movement. If teachers do not implement stretching and warming in learning PJOK, it can affect the occurrence of injury to learners in doing physical activity such as game and sports in school.

Learning as a process of mutual influence between teachers and students in teaching and learning activities. Learning must be done through several stages, from planning, implementation to assessment. Each step must be conditional, the first step is a condition toward the second step, and the second step is a requirement to enter the third step [12].

Data from the field research on the learning process on core activities can be explained in the table II below.
TABLE II. TEACHER ACTIVITY DATA ON LEARNING CORE ACTIVITY

\begin{tabular}{|l|l|l|l|}
\hline \multirow{2}{*}{ No } & \multicolumn{2}{|c|}{ Core activity } & \multicolumn{2}{|c|}{$\begin{array}{c}\text { Frequency } \\
(\%)\end{array}$} \\
\cline { 3 - 4 } & & Yes & \multicolumn{1}{c|}{ No } \\
\hline 1 & The Lesson Subject Mastery & $3(23,1 \%)$ & $10(76,9 \%)$ \\
\hline 2 & The Use of Learning Strategies & $3(23,1 \%)$ & $10(76,9 \%)$ \\
\hline 3 & The use Learning Resources & $3(23,1 \%)$ & $10(76,9 \%)$ \\
\hline 4 & Student involvement & $13(100 \%)$ & $0(0 \%)$ \\
\hline 5 & Process and Results Assessment & $2(15,4 \%)$ & $11(84,6 \%)$ \\
\hline 6 & The use of good languages & $3(23,1 \%)$ & $10(76,9 \%)$ \\
\hline
\end{tabular}

The data in the table II above illustrates the ability of teachers in mastering the learning materials that has not been good and the use of learning strategies have not been optimal and the use of resources or facilities has not been optimal. Involving learners in the learning process physical education done by all teachers, while the assessment on the process and learning outcomes is only implemented by a small number of teachers. The use of good language in the delivery of subject matter is not good and not yet clear, this is one of the factors that determine the students' understanding of the material presented by the teacher.

The subject of Physical Education, Sport and Health is one of the lessons often done outside the classroom or field. Many teachers find it is difficult to give an example of a certain basic technique movement of one sport. This condition occurs because a lot of teachers are old and only a few who master one of the basic techniques according to his specialty. With the existence of multi-media learning, this can be overcome by showing photos or video movement as a whole [13].

Elementary school physical education teachers must know and understand the characteristics of growth and development of school students themselves, then understand and know the appropriate learning strategy for children that age. It is an added value, as an effort to improve the quality of physical education in elementary school [14].

The method in learning is an important thing in achieving the learning objectives, teachers are expected to use various methods in delivering the subject matter so that the learning process can be achieved optimally. Furthermore, Sebtika, et al., said that evaluation is the final process in decision-making that determines the condition, whether a goal of the process has been achieved, especially in relation to the process of teaching physical education [12].

The final activity of learning process of PJOK consists of several sub indicators namely; doing reflection/making summaries and follow-up if students' understanding of the subject matter is considered not obtaining the minimum mastery criteria.

TABLE III. TEACHER ACTIVITY DATA ON THE END ACTIVITY OF LEARNING

\begin{tabular}{|l|l|c|c|}
\hline \multirow{2}{*}{ No } & \multicolumn{2}{|c|}{ Final Activity } & \multicolumn{2}{c|}{$\begin{array}{c}\text { Frequency } \\
(\%)\end{array}$} \\
\cline { 3 - 4 } & \multicolumn{1}{|c|}{ Yes } & No \\
\hline 1 & $\begin{array}{l}\text { doing reflection / making } \\
\text { summaries }\end{array}$ & $3(23,1 \%)$ & $10(76,9 \%)$ \\
\hline 2 & Doing follow-up & $3(23,1 \%)$ & $10(76,9 \%)$ \\
\hline
\end{tabular}


The data in the table III above illustrates that most teachers do not reflect or explain the summary of the final learning activities. Activity is an activity that repeated orally the material that has been taught, so that teachers can know the level of understanding of learners about the material that has been taught. After the reflection, it is necessary to follow up if there are learners who do not meet the minimum mastery criteria, most teachers do not follow up the learning process that has been implemented.

Based on the results of interviews with teachers' principals and supervisors of educational units, it can be concluded that the competence of physical education teachers in 13 Elementary Schools in Sawang, South Aceh, has not shown the maximum implementation in the learning process. This is because not all physical education teachers have physical education background. From 13 schools, there are 3 schools that have teachers with a physical education background and 10 schools have teachers with physical education educational backgrounds. The ability of teachers in the implementation of physical education learning very influenced by the educational background that has been taken by the teacher. The ability to master the material for teachers with non physical education background still needs to be improved. For non physical education teachers, the ability to identify talents, interests, potential, and learning difficulties of learners still needs to be improved. They only peform the learning process is just to fill the teacher absence. They just let the learner to play alone without giving direction.

Teachers who have educational background in 3 elementary schools in Sawang, South Aceh, have good competence in the implementation of learning physical education. The interview results with teachers and principals state that teachers have been able to identify the characteristics of learners well through the physical movements practiced by learners. Teachers are able to practice the movement in accordance with the material in the physical education well to learners. In addition, teachers are also able to perform the learning process in accordance with the syllabus and evaluate the results of learning well.

Good physical education learning that is student-centered learning and emphasis on appropriate learning in the learning process can also encourage students to become active [2]. Teachers should be able to study different types of sports materials for each different learning objective and conduct evaluations and assessments of student learning outcomes [15]. Follow-up needs to be done so that every learner who is not receives information about learning materials well, can obtain additional information about the material with explanations given by teachers and provide additional tasks.

Lesson program in Elementary School in South Aceh is still not good, it can be seen from the findings in the field that most of the teachers do not instruct activities of stretching, warming and apperception activities in the early activities of learning. In the core activities most of the teachers do not master the subject matter of PJOK, do not apply the learning strategy, do not use learning resources and instructional media in accordance with the material, but in the final learning process teachers involve all students. Assessment of learning processes and outcomes is not done by most teachers, but only by the end of the semester. Most teachers have not been able to use the language that appropriate with the students' characteristics. In the final learning activities, most teachers do not reflect and explain the learning activities summary.

The results of this study can be a reference and input for teachers related to their competence in implementing the learning process and for stakeholders as policy makers to increase the competence of Physical Education teachers in Elementary Schools at Sawang, South Aceh.

\section{CONCLUSION}

The teachers' competence in the implementation of learning programs in elementary school Sawang, South Aceh had not run optimally. This could be seen in the preliminary activity that 2 Physical Education teachers performed activities of stretching/ warming and apperception, while 11 teachers did not implement those activities.

In the core activities of learning, there are 3 teachers master the material and 10 teachers who did not master the material. 3 teachers used learning strategies that can provide a stimulus for the implementation of fun learning and 10 teachers did not use learning strategies. 3 teachers using learning media in accordance with the planned subject matter and 10 teachers did not use the learning media. Involving learners in the learning process was conducted by all teachers. 2 teachers conducted an authentic assessment of the process and learning outcomes, while 11 teachers only did the assessment at the end of the semester. 3 teachers used good and clear language so that learners more easily understand the material being taught and 10 teachers were not able to use good and clear language in delivering learning materials.

At the end of learning activities there were 3 teachers do reflection and cooling, but 10 teachers did not perform the final activity. Next, 3 teachers conducted follow-up from the learning process that has been implemented and 10 teachers did not implement the activities.

\section{REFERENCES}

[1] R.T. Octaviansyah and O.W.K. Handayani, "Evaluasi Implementasi Kurikulum 2013 pada Pembelajaran Penjasorkes di Sekolah Menengah Pertama Negeri Kota Palembang," Journal of Physical Education and Sport, vol. 4, no. 2, pp. 179-185, 2015.

[2] P.W. Darst, R.P. Pangrazi, T.A. Brusseau and H. Erwin, Dynamic Physical Education for Secondary School Students (8th ed.), Benjamin Cummings: San Francisco, 2015.

[3] N.W. Wardhani, "Pembelajaran Nilai-nilai Kearifan Lokal Sebagai Penguat Karakter Bangsa Melalui Pendidikan Informal,” Jurnal Penelitian Pendidikan, vol. 13, no. 1, 2016.

[4] T. François and J.S. Shephard, "Physical Education, School Physical Activity, School Sports and Academic Performance," International Journal of Behavioural Nutrition and Physical Activity, vol. 5, no. 10, pp. 60-72, 2008.

[5] C. Lu and A.L. De, "Specifics for Generalists: Teaching Elementary Physical Education," International Electronic Journal of Elementary Education, vol. 1, no. 3, pp.170-187, 2009. 
[6] D. Kirk, "Physical Education, Youth Sport and Lifelong Participation: The Importance of Early Learning Experiences," European Physical Education Review, vol. 11, no. 3, pp. 239-255, 2005.

[7] S. Salmawati, T. Rahayu and L. Lestari, "Kontribusi Kompetensi Pedagogik, Kompetensi Profesional, dan Motivasi Kerja terhadap Kinerja Guru Penjasorkes SMP di Kabupaten Pati," Journal of Physical Education and Sport, vol. 6, no. 2, pp. 198-204, 2017.

[8] A.N. Riza, Soegiyanto and E.R. Rustina, E.R., "Kontribusi Disiplin Kerja, Supervisi Akademik dan Partisipasi Guru dalam Musyawarah Guru Mata Pelajaran (MGMP) terhadap Kompetensi Pedagogik Guru Penjasorkes SMK di Kabupaten Jepara,” Journal of Physical Education and Sport, vol. 4, no. 2, pp. 99-104, 2015.

[9] E. Demir, "Students' Evaluation of Professional Personality Competencies of Physical Education Teachers Working in High Sçhools," US-China Education Review, vol. 5, no. 2, pp. 149-157, 2015.

[10] E.J. Thaib, “Al-Qur'an dan As-Sunnah Sebagai Sumber Inspirasi Etos Kerja Islami,” Jurnal Dakwah Tabligh, vol. 15, no. 1, pp. 1-9, 2015.
[11] Sugiyono, Metode Penelitian Kombinasi (Mixed Methods), Bandung CV. Alvabeta, 2013.

[12] A.N. Sebtika, M.E. Winarno and Sugiyanto, "Evaluasi Program Pembelajaran Pendidikan Jasmani Olahraga dan Kesehatan Menggunakan Analisis SWOT," Jurnal Gelanggang Pendidikan Jasmani Indonesia, vol. 1, no. 2, pp. 218-227, 2017.

[13] L. Sukiyandari, K.S. Soegiyanto and E.R. Rustiana, "Multimedia Bola Basket untuk Pembelajaran Pendidikan Jasmani Olahraga dan Kesehatan di SMA," Journal of Physical Education and Sport, vol. 1, no. 2, pp. 168-173, 2012.

[14] Saryono and S. Nopembri, "Analisis Kebutuhan Pembelajaran Pendidikan Jasmani Olahraga Kesehatan Berbasis Integrated Physical Education Di Sekolah Dasar," Jurnal Pendidikan Jasmani Indonesia, vol. 9, no. 2, pp. 81-86, 2013

[15] S. Amara, Samiha., S.M. Nassib, and B. Mkaouer, "Teaching Process of Future Tunisian Physical Education Teachers During a Professional Training," Journal of Physical Education and Sport, vol. 15, no. 4, pp. 736-743, 2015. 